\title{
POSTMODERN CENSORSHIP REVISITED: A REPLY TO RICHARD DELGADO
}

\section{STEVEN G. GEY $\dagger$}

Richard Delgado's recent response ${ }^{1}$ to my article, The Case Against Postmodern Censorship Theory, ${ }^{2}$ provides a concise example of the phenomenon addressed in my original piece. Professor Delgado's essay illustrates many of the problematic characteristics I find scattered throughout postmodern censorship theory-in particular, its failure to address the broader consequences of proposed doctrinal changes in free-speech jurisprudence, its tendency to slide into rhetorical excess and allegations of bad faith against those who challenge the wisdom of broad speech-regulation proposals, and its political naiveté. Unfortunately, Professor Delgado's response adds little to what he has already said on the subject and does not confront many of the very difficult issues at the heart of this debate. It strikes me as a political response, not an academic one.

At one level, therefore, my inclination is simply to suggest that readers go back to the original sources-my article and the work of various postmodern censorship theorists cited therein-and leave it at that. On the other hand, I fear that some readers will read Professor Delgado's succinct response and avoid wading through the original 104-page document. Those readers will be left with an inaccurate impression of what I said in my article, and an equally inaccurate impression of the real issues in these discussions. To avoid these misunderstandings, I feel obligated to respond to what Professor Delgado said, and to comment briefly on what he did not say.

† John W. and Ashley E. Frost Professor of Law, Florida State University College of Law.

'Richard Delgado, Are Hate-Speech Rules Constitutional Heresy? A Reply to Steven Gey, 146 U. PA. L. REV. 865 (1998).

${ }^{2}$ Steven G. Gey, The Case Against Postmodern Censorship Theory, 145 U. PA. L. REv. 193 (1996). 


\section{PROFESSOR DELGADO AND THE PROBLEM OF DISTORTED PERSPECTIVES}

Professor Delgado seems especially concerned about the fact that my article considers postmodernist proposals to regulate hate speech and pornography in the context of the long history of badly misconceived government efforts to regulate other types of antisocial speech. He even complains that I refer to such proposals as "censorship" and to proponents of the new regulations as "new censors." This is not, as Delgado claims, an effort on my part to heap sarcasm on my adversaries; ${ }^{4}$ I use the words "censorship" and "censor" in their ordinary senses-as objective descriptions of the proposals under discussion. "Censorship" is the act of censoring, and the verb "censor" means "to alter, delete, or ban completely after examination." As I understand it, the proposals of Delgado and similar theorists are intended to "alter, delete, or ban completely" hate speech, pornography, and other types of antisocial expression. Thus, the term "censorship" accurately describes the intent and effect of these proposals. A glance at the dictionary also provides a definition of the noun "censor" that describes precisely the role assumed by Delgado and other proponents of new speech regulations: "[O]ne who lacking official sanction but acting ostensibly in society's interests scrutinizes communications, compositions, and entertainments to discover anything immoral, profane, seditious, heretical, or otherwise offensive."6

Although I intend to convey disapproval by using these terms, I do not believe the use of this terminology automatically determines the outcome of the debate over the legitimacy of new speech regulations. I recognize that people of good faith can honestly disagree about whether censorship is justified in particular circumstances, and I respect the opinions of those who disagree with my position on the matter. But Delgado's refusal even to acknowledge the obvious thrust of his proposals allows him to avoid addressing difficult questions about the implications such proposals will have for a wide range of political, social, and cultural speech. Instead of confronting these issues, Delgado tries to isolate the discussion from numerous other

s Delgado, supra note 1, at 866 n.5.

4 See id. at 865-66 ("One finds ... a rather cold, technical exercise, coupled with sarcasm heaped on his adversaries for thinking the way they do.").

${ }^{5}$ I WEBSTER'S THIRD NEW INTERNATIONAL DICTIONARY OF THE ENGLISH LANGUAGE UNABRIDGED 361 (3d ed. 1961).

${ }^{6} I d$. 
attempts to cede control over communication to a virtually unrestrained political process. More insidiously, Delgado falls back on the recitation of emotional hypotheticals to challenge my analysis, and ascribes to me views that I do not hold and did not assert in my original article.

Perhaps the most egregious example of mistaken attribution is Delgado's claim that I argued against new speech regulations because minorities are "too close to the problem [of hate speech] to write about it objectively." ${ }^{8}$ Likewise, Delgado cites my "contention that minorities have no business writing about hate speech because [they] are blinded by self-interest." ${ }^{99}$ According to Delgado, the fact that I overlook how my "own argument cuts both ways is telling."10 He ascribes this to something called "white transparency," which "shows how the white point of view masquerades as colorless, raceless, and systematically devoid of bias."

These assertions not only misconstrue what I said in my article; they actually attribute arguments to me that I found implicit in the postmodern censorship literature itself. The passages of my article to which Delgado addresses his comments ${ }^{12}$ were a specific response to the claim of postmodern censors that all people are "constructed" by social conditions and therefore view reality in distorted ways. My point was that social-constructionism arguments are inevitably selfdefeating because proponents of such arguments must concede that they, too, are "constructed" and therefore have a distorted perception of reality. Delgado's indignant claim that the "argument cuts both ways" sounds familiar because it was the very point I made in my article.

The most revealing aspect of Delgado's claims regarding my earlier work is that he ignores my specific and unambiguous disavowal of

${ }^{7}$ See, e.g., Delgado, supra note 1 , at 866 (envisioning me assisting a group of fraternity members harassing a lone black undergraduate); id. at 877 (calling the hatespeech controversy "the Plessy v. Ferguson of our age," comparing free-speech arguments to segregationist arguments made in Plessy, and concluding that "history will have no trouble telling us which interest is more morally significant"); id. at 879 (comparing arguments opposing speech regulation to Southern resistance to desegregation).

${ }^{8} I d$. at 871 .

9 Id. at 867 .

${ }^{10} I d$. at 871 .

"Id. at 871-72.

${ }^{12}$ See Gey, supra note 2, at 224-27 (discussing the flaws in postmodernist social constructionism). 
the very view he attributes to me-the view that minorities are "blinded by self-interest" or incapable of writing about these problems objectively. I do not intend to weigh down this response with long excerpts from my previous work, but it is important here to demonstrate how clearly I made this point in the original article. I wrote:

None of this criticism is meant to suggest that Professors Sunstein or Lawrence or any of the other postmodern censors are deluded or irrational or incapable of accurately perceiving or describing reality. I mean only to take note of the fact that the postmodernists cannot escape the corrosive effect of their own arguments regarding social constructionism and distorted preferences. If everyone's view of the world is irretrievably distorted by the observer's socially constructed psyche, then no one, including the postmodern critics of present reality, can escape their own distorted perceptions in order to critique society and suggest solutions to our problems.

Ironically, after zealously attributing to me a proposition I explicitly rejected, Delgado then suggests that I allowed my "zeal" to affect my "scholarly objectivity." 14 Perhaps the syndrome is contagious.

In other, more subtle ways, Delgado misconstrues my position by oversimplifying my claims and finessing the contradictions of postmodern censorship that I detailed in my article. For example, Delgado objects to my characterization of speech regulation as an example of powerful political actors squelching the speech of speakers who lack political power. Delgado objects to the fact that "[I] write[] as though minorities were now in charge and running things." With regard to university speech codes, he argues that "it is our very powerlessness and vulnerability that cause a few universities to consider passing hate-speech rules." ${ }^{\prime 16}$ But in the very next paragraph, Delgado cites an argument he had made previously that campus officials tolerate racist speech because "racist speech benefits powerful white-dominated institutions" by keeping "non-white people on edge, a little off-balance," and eventually "assur[ing] that those of us of real spirit, real pride, just plain leave."

13 Id. at 227.

${ }^{14}$ Delgado, supra note 1 , at 877.

${ }^{15}$ Id. at 875.

${ }^{16} \mathrm{Id}$.

${ }^{17}$ Id. at 876 n.62. Delgado contends that I misquoted this passage in my article, and suggests that I intentionally omitted "an important qualification" that moderated his expansive claim that white university officials are trying to drive out some minority students by permitting "low-grade racism and hassling." Id. at 876 . The "important qualification" that I omitted was Delgado's concession that university officials would 
Delgado neglects to mention the fact, noted in my article, that the university officials whom he criticizes for intentionally benefiting "from a certain amount of low-grade racism in the environment" the same officials that took his advice at the University of Wisconsin and adopted a hate-speech regulation governing the expression of "low-grade racism." Delgado's reductive view of reality not only leads him to ignore inconvenient facts such as these; his view also inhibits his analysis by allowing him to avoid addressing the very complicated political dynamics that produce speech regulations such as the University of Wisconsin speech code. The dynamics of speech regulation do not, as Delgado suggests, automatically correlate with race. Many members of racial minorities do not support speech regulations, while many members of the racial majority support such laws. Moreover, even if every member of every racial minority group supported postmodern speech regulations, they would not have sufficient political power to enact and enforce broad new limitations on speech. Additional support for this legislation therefore must come from politically powerful members of the racial majority. Delgado implicitly acknowledges this fact by chiding me for supposedly suggesting that "minorities [are] now in charge and running things."

By recognizing that minorities are not in charge and thus must rely on the support of other political factions to achieve their goals,

regulate "the very heavy stuff-violence, beatings, bones in the nose" because "[t]hat brings out the TV cameras." Id. at 876 n.62. According to Delgado, "Gey produces his own version [of Delgado's quotation] with the qualification dropped (but marked with ellipses) and then takes me to task for failing to make that very same qualification!" Id. at 876-77 (footnote omitted).

Delgado seems to misunderstand the point of my criticism. My argument is that university administrators have an institutional aversion to any kind of conflict that will create negative publicity and require the allocation of time and energy in responding to angry students, alumni, and legislators. Delgado acknowledges this interest with regard to the "very heavy stuff," but denies that this interest extends to "low-grade" antagonism. I argue that the institutional interest in avoiding conflict and public disputes leads university administrators to overreact against all forms of controversial speech, including what Delgado refers to as "low-grade racism." I specifically dispute Delgado's argument that university administrators tolerate such speech because "they benefit ... from a certain amount of low-grade racism in the environment." Id. at 876 n.62. The "important qualification" that I omitted from Delgado's quote refers to regulations of the "very heavy stuff," not regulation of "low-grade racism"; the passage was therefore irrelevant to my point and omitted for that reason.

${ }^{18} I d$.

${ }^{19}$ See Gey, supra note 2, at 248-51 ("[T]he University of Wisconsin Board of Regents adopted a hate-speech regulation (upon the advice of, among others, Delgado) by a vote of twelve to five.").

${ }^{20}$ Delgado, supra note 1, at 875 . 
Delgado also must acknowledge that speech codes and other regulations of antisocial expression can only be adopted with the support of these different factions. This acknowledgment is problematic for Delgado, because these factions will have interests in regulating speech that are very different from the interests of the postmodern censors. (The odd antipornography alliance of MacKinnon-style feminist activists, conservative Republicans, and elements of the Religious Right provides the clearest example of joint action against speech by political opposites. ${ }^{21}$ ) The need for a political alliance to enact and enforce speech regulations undercuts much of the postmodern case for censorship because it means that the postmodernists cannot guarantee that their policy preferences will guide the application of the speech-regulation system they seek to establish. Once the postmodern censors sweep away strict restrictions on the regulation of antisocial expression, they will have little protection when political activists with whom they sympathize have their own speech declared antisocial.

\section{PROFESSOR DELGado AND THE PROBlem OF GOVERNMENT OVERREACHING}

Professor Delgado responds to the problem of controlling the application of speech-regulation statutes by denying that the problem exists. Delgado argues that "few, if any, of the dangers of censorship loom" when the government adopts postmodern censorship proposals such as university speech codes. ${ }^{22}$ Likewise, Delgado criticizes my "fixation on the supposed political dangers of hate-speech regulation" ${ }^{23}$ and laments my "repeated deployment of the shopworn slippery-slope argument that if courts give government the power to regulate speech in one area, it will soon seize even more and use it in

${ }^{21}$ Although this unnatural alliance is due mostly to the practical political necessities of reducing the availability of explicit sexual expression, there are also deep theoretical similarities in the Mackinnon and conservative approaches to regulating pornography. These similarities can be seen in the final report of Ronald Reagan's notorious Meese Commission Report on Pornography. See ATTORNEY GEN.'s COMM'N ON PORNOGRAPHY, U.S. DEP'T OF JUSTICE, FINAL REPORT (1986) (discussing the history of pornography, child pornography, related laws, and First Amendment concerns); Steven G. Gey, The Apologetics of Suppression: The Regulation of Pornography as Act and Idea, 86 MICH. L. REV. 1564, 1596-606 (1988) (identifying similarities between the approaches of MacKinnon and conservatives, and describing MacKinnon's definition of "harm," which is the focal point of the Meese Commission report).

${ }^{22}$ Delgado, supra note 1 , at 868.

${ }^{23}$ Id. at 870 . 
ways minorities might not like. ${ }^{24}$ Apparently, Delgado believes that these "supposed political dangers" exist mainly in my fertile imagination. "One notices immediately that Gey makes this argument almost entirely by means of hypothetical language," concludes that "[a]nything is possible, of course, but it just has not happened. ${ }^{26}$

The assertion that I fail to provide concrete examples of government overreaching in the regulation of speech will come as somewhat of a surprise to readers who managed to digest the more than three hundred footnotes in my article-many of which refer to specific examples of such excesses. Indeed, a careful reading of Delgado's response reveals that he completely discounts many of these examples on the grounds that they "took place long before hate-speech rules were in effect and were more the product of political excess than lack of First Amendment zeal." ${ }^{27}$ The fact that "political excess" in the pursuit of censorship frequently has been able to override "First Amendment zeal" is precisely my point. Delgado asks us to discount the admitted excesses of previous generations of censors by placing our faith in the judgment and restraint of the new censors. Such faith is unwarranted, however. By their nature, censors are seldom sensitive to the consequences of their actions, and blind faith in those who exercise censorship power will offer little or no protection for those whose views challenge the cherished values of officials representing the status quo.

Delgado's blithe dismissal of my observation that modern censorship proposals pose dangers of overreaching identical in scope to those evident in prior eras of "political excess" provides further cause for hesitation in giving the postmodern censors the power they seek. For example, Delgado asserts without equivocation that "Western democracies that have enacted hate-speech laws, such as Canada, Denmark, France, Germany, and the Netherlands, have scarcely suffered a diminution of respect for free speech. ${ }^{28}$ But even a brief glance at how hate-speech laws actually have been enforced in Western democracies unencumbered by the First Amendment exposes a much more troublesome reality.

\footnotetext{
${ }^{24} I d$. at 873 .

${ }^{25}$ Id.

${ }^{26}$ Id. at 874.

${ }^{27} I d$.

${ }^{28} I d$.
} 
Consider the British experience, for example. One of the first prosecutions under the British statute prohibiting incitement to racial hatred $^{29}$ involved Michael Malik, a.k.a. Michael X, who was the leader of the Racial Adjustment Action Society, a Black Power movement in Britain. $^{30}$ Malik was sent to prison for twelve months for making vaguely threatening statements deemed critical of whites. ${ }^{31}$ Soon after his conviction, four prominent members of another Black Power organization were convicted under the same statute for similar statements they made at Speakers' Corner in Hyde Park. ${ }^{32}$ Among the statements cited in the prosecution's case was one defendant's assertion that "Anglo-Saxons are the number one enemy of the human race and [are] responsible for racialism. Each time we kill a white man in Africa they say we are going back to the jungle, but is not England a jungle?"33

Canadian hate-speech laws have been applied in a similarly uneven fashion. In 1989, soon after Iranian religious officials issued a bounty for the death of author Salman Rushdie, Canadian customs officials used the Canadian hate-speech laws to justify seizing copies of Rushdie's offending novel, The Satanic Verses. The officials acted on the complaint of the Islamic Society of North America, which wanted the book banned. In explaining this action, a spokesperson for the customs department told the Chicago Tribune that "[t]his department's obligation is to protect Canadian society from the importation of materials that don't conform to Canadian values.... We treat complaints we receive quite seriously." ${ }^{34}$ The Canadian authorities' lack of judgment in the Rushdie case was not an isolated incident: The same Canadian law was also used to justify Canadian customs' month-long seizure of a film sympathetic to Nelson Mandela because

${ }^{29}$ See Race Relations Act, 1965, ch. 73 (Eng.) (proscribing "discrimination on racial grounds in places of public resort").

${ }^{30}$ See Regina v. Malik [1968] 1 All E.R. 582, 582 (C.A. 1967); see also Anthony Dickey, Prosecutions Under the Race Relations Act 1965, s. 6 (Incitement to Racial Hatred), 1968 CRIM. L. REV. 489, 493 (describing the case).

${ }^{31}$ See Malik [1968] 1 All E.R. at 583-84 ("I want to tell you about souls. The black man has soul. The white man has no soul. He is a soulless person .... Don't let the thought of prison terrify you. I have been to prison. At first I was terrified but it is a coloured man's job to go to prison. You get to know a lot in prison, a lot that can terrify the white man.").

${ }^{32}$ See Dickey, supra note 30 , at $489,493$.

${ }^{33}$ Sentences Today on Four Coloured Men: Ten Charges Under Race Act, TIMES (London), Nov. 29, 1967, at 3.

${ }^{34}$ Howard Witt, Canada Bans Imports of Moslem Novel, CHI. TRIB., Feb. 18, 1989, § 1, at 2. 
it "stirred ill feelings against white South Africans." 35 Both the Rushdie book and the Mandela film were eventually allowed into the country. But it says something disturbing about the psychology of censorship that Canadian customs officials attended so closely to the feelings of white South Africans and treated complaints against The Satanic Verses "quite seriously" at a time when the novel was a focal point of international efforts on behalf of artistic freedom. These incidents underscore an obvious point that Delgado repeatedly denies: Censors usually take their job seriously, which inevitably leads to official overreaching in the noble service of regulating "bad" ideas.

Part of the problem in applying hate-speech laws consistently is that such laws often are premised explicitly on the desire to suppress a particular point of view. Rigorous adherence to such a premise will require officials to suppress even ambiguous expressions of the prohibited viewpoint, which will lead to official misjudgment and suppression of legitimate debate. Contrary to Delgado's confident assertions about the benign effects of hate-speech regulation in other Western countries, evidence from these countries confirms the tendency towards overzealous suppression.

Consider, for example, the application of French hate-speech laws to the works of historians who challenge accepted accounts of recent historical events. These laws were first applied to University of Lyon Professor Robert Faurisson and the French magazine Le Choc du Mois [The Shock of the Month]. Faurisson and Le Choc were convicted under a 1990 French hate-speech law criminalizing expression disputing the existence of the Holocaust. ${ }^{36}$ The conviction was based on an article written by Faurisson in which he asserted that "no Jews were gassed to death in World War II concentration camps."

Given the absurdity of Faurisson's views, this prosecution caused little distress. But the French government soon applied the same law to Roger Garaudy's book, The Founding Myths of Israeli Policy. ${ }^{98}$ Unlike Faurisson, Garaudy does not deny that the Nazis killed millions of Jews. Rather, Garaudy's offenses are that he chooses to call these killings "pogroms" or "massacres" rather than "genocide" or a

${ }^{35}$ Clarence Page, Nattering Nabobs of Nannyism, CHI. TRIB., Sept. 9, 1990, § 4, at 3.

${ }^{36}$ See French Academic Condemned for Denying Existence of Nazi Gas Chambers, AGENCE FR.-PRESSE, Dec. 9, 1992, available in 1992 WL 8556856.

${ }^{37} I d$.

"see Gail Russell Chaddock, Cleric's Comments Ignite the Fury of French Media, CHRISTIAN SCI. MONITOR, July 25, 1996, at 5. 
"Holocaust," exaggerated the Holocaust in order to help gain political support for the establishment of the state of Israel."

The fact that a criminal prosecution could be based on a historian's choice of nouns is troubling, even when applied to a Holocaust skeptic. Moreover, the use of French hate-speech laws to sanitize historical debate has not stopped with Garaudy, nor has it been limited to discussions of the Holocaust. In 1995, a French court fined Princeton Professor Bernard Lewis the equivalent of $\$ 2000$ for comments he made in an interview with Le Monde about Turkish massacres of Armenians in 1915. Lewis's infraction was to deny that the word "genocide" could be applied legitimately to the Armenian situation, since, in Lewis's view, there was no evidence that Turkey engaged in a "deliberate, planned extermination or attempted extermination of a people."

The French effort to control historical debate underscores an obvious point that Delgado ignores: Although they cannot be described as repressive regimes overall, European governments unquestionably exhibit far more authoritarian attitudes towards the official regulation of speech than is acceptable in this country, and this authoritarian attitude is reflected in the scope and application of European hatespeech law. European countries have never institutionalized the uniquely American belief that citizens can sort out truth and falsehood for themselves, and likewise can recognize and respond appropriately to hatred when they hear it. It is deeply inconsistent with the American tradition of free speech to put a historian in jail for publishing a false or offensive account of history, much less for characterizing a historical incident in a way that the government finds intolerable. Thus, I agree with Delgado's observation that hatespeech laws have not diminished other Western countries' respect for free speech, but only because these countries never displayed the characteristic American respect for free speech in the first place.

${ }^{39}$ French Author Investigated for Doubting Holocaust, REUTERS WORLD SERV., Apr. 25, 1996, available in LEXIS, News Library, Reuwld File.

${ }^{40}$ Nicholas Goldberg, Palestinian View of Holocaust, NEWSDAY, Jan. 22, 1998, at A25, available in 1998 WL 2655448.

11 Jonathan Rugman, Memory of Slaughter Haunts a Nation, GUARDIAN (London), Aug. 26, 1995, at 16. Although the French court held that the law used against Faurisson and Garaudy was limited to denials of the Nazi Holocaust, and therefore inapplicable to Lewis, the court nevertheless achieved the same end by ruling against him on the grounds that he had "insulted the Armenian nation." "Hate Speech" Again, Abroad, WASH. POST, Sept. 9, 1995, at A16. 
Delgado's failure to recognize the problems accompanying hatespeech regulation in other countries is not the only example of the flawed and weak evidence he musters to support his contention that governments will not overreact when applying postmodern censorship statutes. In response to my skepticism about the application of university speech codes, for example, Delgado cites only a conversation with Professor Michael Olivas of the University of Houston. According to Delgado, this conversation confirms that " $[c]$ olleges that have enacted anti-hate-speech rules have not proceeded ineluctably to enact even more sweeping rules or put everyone in jail." ${ }^{, 2}$

This broad statement is correct, but Delgado fails to point out one of the main reasons why abuses have been kept to a minimum-that is, that several broad university speech codes have been struck down on First Amendment grounds by the federal courts. ${ }^{43}$ The factual background of one of these decisions, which involved the University of Michigan's speech code, provides a cautionary lesson on the kinds of abuses that could be expected if such codes routinely were upheld. ${ }^{44}$ Other prominent attempts to enforce broad speech codes, such as the "water buffalo" incident at the University of Pennsylvania, reinforce the point. ${ }^{45}$ Although Delgado persists in advocating strong

${ }^{42}$ Delgado, supra note 1, at 874.

${ }^{43}$ The two most prominent cases involved the speech codes of the University of Michigan and the University of Wisconsin. See UWM Post, Inc. v. Board of Regents of the Univ. of Wis. Sys., 774 F. Supp. 1163, 1181 (E.D. Wis. 1991) (holding the speech code unconstitutional); Doe v. University of Mich., 721 F. Supp. 852, 867 (E.D. Mich. 1989) (noting that the speech code was overbroad and unduly vague).

14 The court found that "the record of the University's enforcement of the Policy over the past year suggested that students in the classroom and research setting who offended others by discussing ideas deemed controversial could be and were subject to discipline." Doe, 721 F. Supp. at 861 . One student was subjected to a formal hearing under the Michigan speech code for stating "in the context of a social work research class that he believed that homosexuality was a disease that could be psychologically treated." Id. A second student was charged with violating the code "for reading an allegedly homophobic limerick during a scheduled class public-speaking exercise which ridiculed a well known athlete for his presumed sexual orientation." Id. at 865 . A third student was charged by a professor for violating the code after the student repeated a former black dentistry student's assertion that minority students had a difficult time in a particular class, and were not treated fairly in that class. See id. at 866. In the face of such episodes, it is difficult to credit Delgado's dismissive assertion that "[a]nything is possible, of course, but it just has not happened." Delgado, supra note 1 , at 874 .

${ }^{15}$ In this incident, five black University of Pennsylvania students charged that a white student violated the University's speech code by "calling them 'water buffalo' after they refused to break up a party in front of his dormitory." Michael deCourcy Hinds, Blacks at Penn Drop a Charge of Harassment, N.Y. TimEs, May 25, 1993, at Al0. According to the student who was charged with violating the code, "water buffalo' was 
university speech codes, many universities have now learned an important lesson about free speech: The University of Michigan and the University of Wisconsin significantly narrowed their codes after losing in court, ${ }^{46}$ and the University of Pennsylvania likewise abandoned the speech code used in the "water buffalo" case on the ground that the code was "legalistic and counterproductive."

Delgado's response to my concerns about the abuses resulting from the enforcement of the Canadian Supreme Court's recent Butler decision $^{48}$ is as unconvincing as his sanguine description of university speech-code enforcement. Delgado's entire discussion of the Canadian case is a curt assertion that my claim of abusive enforcement "has been refuted by later investigation." 99 The only citation supporting this assertion is to a statement by Catherine MacKinnon and Andrea Dworkin. ${ }^{50}$ Not surprisingly, MacKinnon and Dworkin deny that their censorship proposals (which the Butler decision largely adopts) are responsible for the Canadian government's numerous post-Butler seizures of offending books and films (including many materials directed at homosexuals and even some feminist works by authors such as Dworkin ${ }^{51}$ ). MacKinnon and Dworkin dismiss the Glad Day Bookstore case that I cited in my article ${ }^{52}$ as an early aberration in the application of Butler. According to Delgado, the decision was based on "the old, moralistic standard for obscenity, rather than the new, harmto-women standard."

a loose translation of a mild Hebrew epithet for a rude person." Id. The charges were later dropped after the five students who brought them claimed that university officials had interfered in the adjudicatory process. See id.

${ }^{46}$ See William Celis III, Universities Reconsidering Bans on Hate Speech, N.Y. TIMES, June 24, 1992, at A13 (reporting the action taken by the two schools).

${ }^{17}$ Penn to Alter Harassment Rules to Balance Free Speech and Privacy, N.Y. Times, Nov. 17,1993 , at A25.

${ }^{4 s}$ See Regina v. Butler, 89 D.L.R.4th 449, 450-51 (1992) (upholding the illegality of socially harmful obscene materials, but not materials with redeeming purposes, such as scientific, artistic, or literary value).

${ }^{49}$ Delgado, supra note 1 , at 874 .

${ }^{50}$ See id. at 875 n.53.

${ }^{51}$ See Gey, supra note 2, at 247 n.154 (noting that two of Andrea Dworkin's books were briefly detained as obscene).

${ }^{52}$ See id. The bookstore was prosecuted for selling the lesbian magazine Bad Attitude. The judge in the case rejected the bookstore's contention that since no men were portrayed in the magazine, Butler did not apply. See Pat Califia, Dangerous Tongues, in FORBIDDEN PASSAGES: WRITINGS BANNED IN CANADA 9, 17 (1995) (noting that the bookstore owner was found guilty and that Butler did apply).

${ }^{53}$ Delgado, supra note 1, at $875 \mathrm{n.53}$ (citing the statement by MacKinnon and Dworkin). 
Delgado's presentation of MacKinnon's apparent disagreement with the result in the Glad Day case should be placed in context with what MacKinnon has said elsewhere about the same case. MacKinnon discussed this case in an interview with a reporter from the New Yorker. According to the New Yorker, "it is primarily the language of the Glad Day opinion that [MacKinnon] objects to, and not necessarily the result in the case. ${ }^{, 54}$ Indeed, MacKinnon even told the New Yorker reporter that "I am not necessarily at all clear that Glad Day should not be prosecuted, ${ }^{, 55}$ thus illustrating the practical congruence of the new, postmodern censorship schemes and the "old, moralistic standard for obscenity." ${ }^{56}$

Delgado's attempt to explain away the repressive results of Butler also contrasts sharply with the views of publishers, writers, film makers, and bookstore owners who have to operate under the Canadian regime. As lesbian author (and Canadian censorship target) Pat Califia has pointed out:

With the Butler decision as fuel, Customs seizures escalated to an alarming degree. Material that featured anal sex could subsequently be seized on the grounds that it was "violent and degrading." Feminist antiporn laws are not enforced by feminists. They are enforced by straight, homophobic men who think that lesbianism is much more dangerous and degrading to women than domestic violence or rape. ${ }^{57}$

The Little Sisters Book and Art Emporium, one of only four gay and lesbian bookstores in Canada, has been fighting seizures of books by Canadian customs for many years. ${ }^{58}$ The bookstore eventually filed suit challenging the constitutionality of the customs officials' authority to seize a broad range of gay and lesbian materials. The bookstore's lawsuit was pending when the Canadian Supreme Court issued its Butler decision. The subsequent British Columbia Supreme Court decision in the Little Sisters case cited Butler to justify upholding the constitutionality of the customs officials' prior restraint authority over gay and lesbian literature. ${ }^{59}$ According to the British Columbia court,

${ }^{54}$ Jeffrey Toobin, X-Rated, NEW YORKER, Oct. 3, 1994, at 70, 77.

${ }^{35} I d$.

${ }^{56}$ Delgado, supra note 1 , at 874-75 n.53.

${ }^{37}$ Califia, supra note 52 , at 18.

${ }^{58}$ For an account of the bookstore's anticensorship efforts, coauthored by the store's manager, see JANINE FULLER \& STUART BLACKLEY, RESTRICTED ENTRY: CENSORSHIP ON TRIAL (2d ed. 1996).

${ }^{39}$ See Little Sisters Book \& Art Emporium v. Minister of Justice, 131 D.L.R.4th 486, 537 (B.C. 1996) (" $[\mathrm{H}]$ omosexual pornography can be obscene within the meaning ascribed to that word by Butler."). 
Butler could not be confined to heterosexual material that is demeaning to women because "[Butler] speaks of harm caused generally by obscenity." The court concluded that "Butler has settled the point that there is a rational connection between [Canadian obscenity laws] and the objective of preventing obscenity, both heterosexual and homosexual." ${ }^{61}$ After reflecting on the post-Butler actions of the Canadian government, the observations of those affected by those actions, and the interpretation of Butler by the Canadian courts themselves, it is difficult to see how Delgado can justify his assertion that the concerns I expressed in my earlier article about censorship under the Butler decision have "been refuted by later investigation."

The Canadian, British, and French experiences (not to mention the Nigerian, Burmese, and Chinese cases cited in my original arti$\mathrm{cle}^{63}$ ) demonstrate the persistent danger that officials will abuse their broad powers over speech. Contrary to Delgado's suggestion, these dangers are not merely a "hypothetical." been spared the worst excesses seen in other countries, it is because, as the British Columbia Supreme Court pointed out in its Little Sisters opinion, free-speech rights in this country "emanate from a very different constitutional heritage in which free speech and privacy are relatively unfettered constitutional rights." ${ }^{65}$ It is obviously Delgado's prerogative to argue that the "relatively unfettered rights" that currently characterize our constitutional environment should be brought into line with the more restrictive policies that prevail elsewhere, but denying the well-documented infringements of speech that occur in such systems does not provide a very compelling argument for his position.

${ }^{60} I d$. at 537.

${ }^{61}$ Id. at 542.

${ }^{62}$ Delgado, supra note 1 , at 874 .

${ }^{63}$ See Gey, supra note 2, at 294-95 \& nn.294-96 (noting that these countries have political systems which are "unburdened by the structural protections of individual liberty").

${ }^{64}$ See Delgado, supra note 1, at 873 (stating that my "argument that if courts give government the power to regulate speech in one area, it will soon seize even more and use it in ways minorities might not like" is made "by means of hypothetical language").

${ }^{65}$ Little Sisters, 131 D.L.R.4th at 533. 


\section{THE QUESTION OF TONE AND THE MISSING PIECES OF PROFESSOR DELGADO'S CRITIQUE}

Ironically, many of Professor Delgado's most caustic remarks concern the muted tone of my article. Delgado accuses me of engaging in "a rather cold, technical exercise," which lacks "any serious consideration of countervailing interests. ${ }^{\prime 66}$ In contrast, Delgado's response is visceral and heated. Our differences in style reflect similar differences in emphasis. In my article, I focus on the illogic of postmodern censorship proposals and the structural difficulties of removing current restrictions on government regulation of speech. In his response, Delgado seeks to shift the focus of First Amendment debate away from general arguments about the abstract structure of speech regulation and focus instead on the merits of government suppression in each of his examples of antisocial speech. From my perspective, the need to control the exercise of government authority over individual intellect and expression determines which particular examples of antisocial speech should be permitted. Conversely, from Delgado's perspective, the need to suppress particular examples of antisocial speech dictates the general structure of government authority over such speech.

Although I believe that the weight of the evidence strongly favors my approach, I recognize that Delgado's position deserves consideration and is worthy of a thorough and serious response. Delgado does not make the same concession to those who disagree with him. Delgado's approach to the regulation of speech carries with it an implicit corollary that renders honest debate about these matters difficult, if not impossible. Under Delgado's approach, those of us who advocate broad protection of antisocial speech are regarded as the willing handmaidens of Nazis, racists, pornographers, and other nefarious speakers to whom we would offer First Amendment protection. ${ }^{67}$ Structural arguments about the protection of speech, therefore, are incurably tainted by the evil motives of those who ultimately would receive this protection.

In the most obvious example of this tendency, Delgado envisions me leaping to the defense of a group of thugs attacking "a lone black undergraduate walking home late at night." "Leave them [the

${ }^{66}$ Delgado, supra note 1 , at 865-66.

${ }^{67}$ See id. at 866.

${ }^{63}$ Id. Depending upon the precise circumstances of this encounter, the situation Delgado describes could easily fall within either the fighting words or "true threat" 
thugs] alone," Delgado has me saying. "They have a right to do what they are doing." ${ }^{39}$ Elsewhere in his article, Delgado suggests that my defense of racist speech may have roots in my deeper ideological sympathies with hateful racists. Delgado asserts that "the hate-speech controversy is the Plessy $v$. Ferguson of our age," (sarcastically?) that "[m] ost of us today-I assume Gey, as wellbelieve that Brown, not Plessy, was rightly decided." ${ }^{71}$ Having conceded that I may not be a segregationist, however, he returns to the analogy to suggest that I may be one after all: " $[\mathrm{A}] \mathrm{s}$ with Plessy and the Southern resistance to Brown, the opposition sees itself as highly principled. We are not for discrimination, they say. Oh, no. Rather, higher principles, they argue (there, neighborhood schools, here free speech), are at stake." ${ }^{\text {22 }}$ If I read this correctly, Delgado is arguing that the free-speech principles I defend are only a cloak for my unstated agreement with the racist proposals of the speakers whose rights I defend. At least I have good company; Delgado pointedly notes that my free-speech "heroes," John Locke, Thomas Hobbes, and Oliver Wendell Holmes, also had racial "blind spots."

All of these veiled suggestions of my ulterior motives and racial insensitivity have an obvious rhetorical effect. It is a venerated tactic: undermine an opposing argument by attacking the integrity of your opponent. Here, he impugns arguments that noninciting racist and other antisocial speech are constitutionally protected by suggesting that anyone taking this position is himself a hateful racist, or at least is in cahoots with such people.

Delgado's response cleverly relies on a heartfelt emotional appeal to laudable human instincts of fair play and empathy for society's innocent victims. Abstract theoretical arguments about the structure of rights and liberties and the necessity for systematic, generalized, and consistent limits on the application of political power sound hol-

exceptions to the First Amendment, doctrines which I have never suggested the courts cannot enforce. Delgado ignores this possibility, perhaps because he insists upon characterizing me (inaccurately) as a First Amendment absolutist. See id. at 875 ("Gey, like other First Amendment absolutists ....."). The postmodern censors' frequent and inaccurate use of the label "absolutist" to describe those who disagree with them is a common phenomenon within the postmodern censorship literature, which I noted in my original article. See Gey, supra note 2, at 218-20 \& nn.83-84.

${ }^{69}$ Delgado, supra note 1 , at 866.

${ }^{70} I d$. at 877 (footnote omitted).

${ }^{7} I d$. at 879.

${ }^{72} I d$. (footnote omitted).

${ }^{73}$ Id. at 867. 
low, distant, and flat when set beside the graphic and compelling accounts of those who have been wronged by society's brutes. And yet, in some ways, it is the very power such accounts possess, to draw us into the world of righteous indignation, that makes them so dangerous as justifications for the exercise of broad governmental power. Indignation toward those who violate society's most cherished mores leads political actors to believe too strongly in their own abilities to gauge and address injustice immediately, harshly, and without external constraints. In such circumstances, the complicated, multifaceted realities, reflected in human expression, tend to get shoehorned into rigidly dichotomous regulatory structures: black and white, good and bad, right and wrong. At the same time, justifications for the application of power in the service of truth and justice tend to take on a life of their own, and subtleties get lost in the process of identifying and responding to a demonized social evil.

One can see evidence of this in Delgado's response to my article. In focusing on the evil nature of the ideas whose expression my theory would protect, Delgado fails to respond (or responds only superficially) to my main arguments against postmodern censorship. I have already noted two examples. First, Delgado either ignores the many examples of official abuse of censorship powers I discussed in my original article or dismisses them offhandedly as belonging to another era. ${ }^{74}$ Second, he does not address the self-contradictory nature of social-constructionism arguments, choosing instead to twist those arguments into a claim-contradicted explicitly in my articlethat I believe minorities are self-deluded and should not be allowed to speak on the subject of hate speech. ${ }^{75}$

At least in those two examples Delgado acknowledges that an argument has been made. Delgado provides no response whatsoever to many other issues raised by my original article. For example, Delgado does not even address the empirical, ${ }^{76}$ political, $^{77}$ and theoretical ${ }^{78}$ flaws I identified in the social-constructionist aspect of postmodern censorship literature. He does not respond to my argument that the

7 See id. at 874 (stating that my examples come from "mainly McCarthy-era witch hunts"); supra Part II (responding to Delgado's claim and providing additional examples to bolster my argument).

${ }^{75}$ See supra text accompanying notes 8-14 (discussing Delgado's misconstrual of my earlier article).

${ }^{76}$ See Gey, supra note 2, at 221-24.

7 See id. at 227-31.

${ }^{78}$ See id. at 231-33. 
postmodernist concept of direct government control over private political and social attitudes contradicts the most basic notions of democracy-that an independent citizenry should control the government, rather than vice versa. ${ }^{79}$ He derides my claim that postmodern censorship proposals are theoretically indistinguishable from prior censorship regimes. ${ }^{80} \mathrm{He}$ does not, however, explain why government intervention to "prevent private harm" ${ }^{\text {"11 }}$ in the form of racist speech is logically distinguishable from, for example, government intervention to "prevent private harm" in the form of violent revolutionary advocacy. ${ }^{82}$ In both instances, the government is intervening to suppress private speech that attacks some central value that the government represents, to the detriment of open and vibrant public discourse.

Perhaps most importantly, Delgado does not indicate how he would apply his theory that collective values should trump individual liberties outside the First Amendment context. ${ }^{83}$ The central argument made by Delgado and other postmodern censors is that collective values in the form of equality or antisubordination should limit the individual right to speak freely against such values. The First Amendment, however, is not the only protection against the aggressive enforcement of collective values. The Fourth, Fifth, Sixth, and Eighth Amendments also impose limits on the pursuit of collective goals. If the postmodern arguments against strong First Amendment protection reflect a more general willingness to subordinate individual constitutional rights to collective goals, are the other portions of the Bill of Rights now subject to limitation as well? If not, why not? Also, if the postmodern censors seek to limit only the First Amendment, how can they explain why the First Amendment should be treated with less respect than other protections of individual liberty that are based on precisely the same deep skepticism that any faction exercising political power can be trusted to limit its own excesses? Conversely, if the postmodern censors would apply their theory more

${ }^{79}$ See id. at 241-44 (explaining the "antidemocratic" flaw in the postmodern argument).

${ }^{80}$ See Delgado, supra note 1, at 874 (arguing that my examples of censorship "took place long before hate-speech rules were in effect and were more the product of political excess than lack of First Amendment zeal").

${ }^{81} I d$. at 868.

${ }^{82}$ See Gey, supra note 2, at 215-16 (discussing Gitlow v. New York, 268 U.S. 652 (1925)); id. at 287-89 (discussing the similarities between postmodern censorship rationales and the logic employed in the early Espionage Act cases).

${ }^{83}$ I raise this issue in my original article. See id. at 287-90. 
broadly, to limit all constitutional protections of individual rights, what does that say about a constitutional theory that would be willing to dilute hard-won institutional prohibitions on warrantless searches, self-incrimination, and torture? Who but the truest of true believers in postmodern descriptions of reality would be willing to endorse such a wholesale restructuring of our constitutional scheme?

These are serious questions, which in my view cannot be answered satisfactorily by Delgado and other defenders of postmodern censorship proposals. Delgado chooses to ignore these questions in favor of subtly suggesting that these issues are not really my concern at all. According to Delgado, the principles that lie behind the questions are worthy of no greater respect than the segregationists' stated preference for neighborhood schools. ${ }^{84}$ I suppose that response plays well to those who are already convinced that postmodern censorship is a good thing, and that all those who oppose the theory are evil hatemongers. From the perspective of an outsider, however, Delgado's harsh response to some honestly posed questions does nothing to allay my many concerns about the dangers of postmodern censorship theory. In the absence of more compelling arguments to the contrary, I stand by my original article in every respect.

${ }^{84}$ See Delgado, supra note 1, at 878-79 (drawing a parallel between those who argued for neighborhood schools and those who argue for free speech). 
